\title{
Ou-Testamentiese Wetenskap in die Nederduitsch Hervormde Kerk
}

\author{
P M Venter \\ Universiteit van Pretoria
}

\begin{abstract}
Old Testament scholarship in the Nederduitsch Hervormde Kerk

Old Testament scholarship in the Nederduitsch Hervormde Kerk is characterized by three factors. The study of Semitic languages influences Old Testament scholarship to be a literary-historical, communication-orientated study of the Old Testament. The reformationorientated dialectical theology paradigm directs its results towards a pluriform existential relationship between God and man. In the framework of the university Old Testament scholarship stands in dialogue with the other theological disciplines and all the other sciences, presenting relevant values to the community.
\end{abstract}

\section{INI EIDING}

Ou-Testamentiese Wetenskap (OTW) is, kripties gedefinieer, die wetenskaplike hantering van die bundel klassieke geskrifte wat met die versamelnaam 'Ou Testament' aangedui word. Wat hierdie 'wetenskaplike hantering' behels, word deur verskillende faktore bepaal. Die mees grondliggende stel faktore het te doen met die terminologie wat gebruik word: dat dit klassieke geskrifte is met ' $n$ eie aard; dat hierdie bepaalde geskrifte in een bundel opgeneem is; dat dit genoem word 'Ou Testament' (teenoor ' $n$ ander, Nuwe Testament). Hierdie artikel is egter 
nie op hierdie sake gerig nie, maar op 'n tweede stel faktore. Hier word aandag gegee aan die faktore wat die beoefening van OTW binne die Hervormde Kerk bepaal, veral soos dit bedryf word in die Nederduitsch Hervormde Kerk se afdeling van die Fakulteit Teologie aan die Universiteit van Pretoria. OTW was en word hier bepaal deur'n stel van drie faktore:

- die studie van Semitiese tale;

- die definisie van teologie in die bepaalde fakulteitsafdeling;

- die definisie van wetenskap aan die universiteit en die verhouding waarin dit teologie tot ander wetenskappe stel.

\section{DIE ROL VAN SEMITIESE TALE}

Ou-Testamentiese Wetenskap het 'n historiese band met Semitiese Tale aan die Universiteit van Pretoria. Dit is daaraan te wyte dat die dosente in Hebreeus aanvanklik ook Ou Testamentiese Eksegese doseer het. Die onderskeie departemente het slegs een dosent gehad. Sy vakbenadering het bepaal hoe die vak beoefen is. Waar dieselfde persoon twee departemente beman het, was sy vakbeoefening deurslaggewend in albei departemente. A C Patterson was professor in Klassieke Tale en Hebreeus vanaf 1908 tot 1923 . Hy het vanaf 1917 tot 1923 Hebreeus gedoseer (Potgieter 1989:5), en daarnaas ook die lesings in Ou-Testamentiese Eksegese aangebied. B Gemser het vanaf 1926 tot 1947 beide die leerstoele in Semitiese Tale en in die departement OTW beklee. Eers vanaf 1948 tot en met sy emeritaat in 1955 het hy uitsluitlik OTW doseer. Sy opvolger by Semitiese Tale was A van Selms. Hy was sedert 1938 senior lektor in Semitiese Tale. Hy het buiten Semitiese tale ook nog die vak Argeologie by OTW gedoseer. Dit het hy tot in 1962 gedoen. E S Mulder het Gemser as hoof van die Departement OTW in 1956 opgevolg. Sy 'akademiese loopbaan het reeds in 1929 begin toe hy van tyd tot tyd deeltyds...dosent in Semitiese Tale aan die Transvaalse Universiteitskollege....' was (Breytenbach 1992: 102). Ook J P Oberholzer, wat hom in 1971 opgevolg het, was tydelik-deeltydse dosent in Hebreeus aan die Universiteit van Pretoria gedurende die jare 1955. 1959. Die huidige departementshoof, A P B Breytenbach, was vanaf 1968 tot 1973 dosent in Semitiese Tale.

Daar was oor die jare 'n hegte verbintenis tussen Semitiese Tale en Teologie. Dit het beteken dat '...Semitiese Tale tradisioneel nie alleen aanvullend tot verskeie teologiese dissiplines soos Ou en Nuwe Testament en Godsdienswetenskap bestaan het nie, maar dikwels deur noodsaaklike eie aksente 'n selfstandige bydrae tot die vorming van teologiese studente gelewer het' (Potgieter 1989:8). In die geval van OTW was Semitiese Tale nie net aanvullend tot OTW nie, maar ook toonaange- 
wend. Dit het te doen met die genoemde dubbele verbintenis van dosente aan Semitiese Tale sowel as OTW. Die metodes en wetenskapsbenadering wat in die een dissipline gevolg is, is daardeur noodwendig op die ander oorgedra. Hierdie tendens is deur die bepaalde struktuur van teologiese opleiding versterk. Deur die kurrikulère plasing van Hebreeus in die vooropleiding en OTW in die daaropvolgende teologiese nagraadse opleiding, loop dit noodwendig daarop uit dat Semitiese Tale as die basis wetenskap dien en die invloed van Semitiese Tale op OTW groter sal wees as omgekeerd. As vrug van die Kerkhervorming, met sy klem op die Bybel in sy oorspronklike vorm, is dit tot vandag toe ' $n$ aksioma in OTW dat OTW gebonde is aan die literère aard van die Ou Testament en dat alle ondersoek daarvan by literêre analise begin. Wetenskaplike studie van die Ou Testament begin by die oorspronklike teks en kan nie sonder kennis van Hebreeus en die metodes wat in Semitiese Tale gebruik word, uitgevoer word nie. Die Ou Testament is 'n antieke dokument wat 'n eie aard het en nie anders bestudeer kan word as met die toepaslike historiese en literere dissiplines wat in die Semitiese taalwetenskap ontwikkel is nie. Daarsonder kan bestudering van die Ou Testament nie op wetenskaplikheid of teologiese bruikbaarheid aanspraak maak nie:

Nur wenn darüber einhellige Klarheit besteht, dass der wissen-schaftliche Charakter alttestamentlicher Forschung steht und fallt mit einer nach allen Seiten hin aufgeschlossenen historisch-kritischen Arbeit, die die mannigfachen Methoden und Ergebnisse literarischer, historischer, religionsgeschichtlicher und religionspsychologischer Forschung zu handhaben und fruchtbar zu verwerten versteht, hat es überhaupt eınen Sinn, von der theologischen Aufgabe der alttestamentlichen Wissenschaft zu reden.

-(Weiser 1961:184)

Wat Weiser hier reeds in 1935 onder woorde gestel het, is tekenend van die rigting waarin OTW oor die jare en tot op hede beweeg het. Die Ou-Testamentiese Eksegese wat in die twintigerjare gedoen is, het 'n sterk literêre inslag gehad. Die gedeeltes wat bestudeer is, is binne die konteks van die boek waarin dit voorkom, hanteer met besondere aandag aan die samestelling van die boek en die interpretasie van die teks. Daarna het enige vraagstukke wat uit hierdie ondersoek mag voortspruit, gevolg - hetsy dit van leerstellige, etiese of historiese aard was. Met Gemser se koms in 1926 is die tradisionele Europese benadering tot die vakgebied van Semitiese tale op die vakbeoefening in Suid-Afrika oorgedra '...met die wyse warop hy historiese en literêre metodes in sy wetenskapsbeoefening gebruik het' 
(Potgieter 1989:6). Die gebruik van die histories-kritiese benadering in sy vakbeoefening toon dat daar '.... in Gemser se teologiese denke duidelike spore te vind is van die sogenaamde Etiese Teologie wat in Nederland opereer vanaf die helfte van die negentiende eeu tot die helfte van die twintigste eeu...' (Oberholzer 1992c:91). Danksy die lang verbintenis met die Nederlandse Hervormde Kerk en die feit dat die Hervormde predikante van die negentiende eeu oorwegend in Nederland opgelei is, was hierdie benadering nie vreemd vir die teologiese fakulteit of vir die Hervormde Kerk nie. Die tradisie van die Etiese Teologie was reeds goed gevestig in die teologiese denke van die Hervormde Kerk. Daarin kan 'n verdere rede aangewys word hoekom Semitiese Tale soveel invloed op OTW uitgeoefen het. OTW is in 'n tipe denkklimaat beoefen wat ontvanklik was vir die wyse waarop 'n dosent soos Gemser sy vakgebied benader het. Sy wetenskaplike metateorie kon net so van Semitiese tale op OTW oorgedra word.

Die rol wat die Ou Nabye Ooste in die vakbeoefening van Gemser gespeel het en die aandag wat hy aan die tale en kulture daarvan gegee het (vgl Oberholzer 1992c:83), kan ook grootliks teen die agtergrond van die Etiese Teologie verstaan word. Die klem het by hom baie swaar op eksegese gelê. Bybelstudie waarin historiese en literêre metodes toegepas is op die Bybeldokument, was vir hom die belangrikste deel van die teologie (Oberholzer 1992c:84). Alhoewel hy hom nie maklik gewaag het aan 'n algemene teologie van die Ou Testament nie (Oberholzer 1992c:85), het daar wel '...in die denke van Gemser oor die Heilige Skrif, die geloof en die ampsbediening 'n organiese eenheid bestaan' (Oberholzer 1992c:88). Die histories-kritiese wetenskaplike bestudering van die Ou Testament binne sy antieke kultuurwêreld het vir hom selfs ook 'n organiese eenheid met die bestudering van die Nuwe Testament en die teologiese arbeid van die kerk gevorm. By geleentheid lewer hy ook pleidooi vir die integrasie van wetenskapsbeoefening in die lewe van die volk, in die geheel van die universum van wetenskappe, in die wêreldwye internasionale beoefening daarvan en in die navorsing na die onbekende.

Ook die invloed wat Gemser se opvolger by Semitiese Tale, A van Selms, op die beoefening van OTW gehad het, was aansienlik. Tereg merk Potgieter (1989:6) op: '...onder sy bekwame leiding is 'n hele geslag van Ou Testamentici en Semitici gevorm wat self later hoofde van departemente aan verskeie Suid-Afrikaanse universiteite geword het'. Oberholzer (1992b:73) sien die invloed van Van Selms op die departement OTW in ' $n$ '...noukeurige deeglikheid in die filologie en integrering van wetenskap en teologie'. Soos Gemser het sy denke binne die stroom van die Etiese rigting beweeg en kon hy hom selfs ook onomwonde met die dialektiese teologie van Karl Barth vereenselwig. Hy beoefen teologiese Bybelkritiek waarin hy 
vanaf noukeurige navorsing van teks, taal en konteks deurbeweeg na die onderliggende teologiese struktuur en uiteindelik die breër teologiese konteks. Hy vermy 'n biblisistiese benadering en hou aan die eenheid van die Skrif vas. Vanuit die Christelike teologie kan daar volgens hom nie regstreeeks na die Ou Testament gegaan word nie, maar moet dit altyd oor die weg van die Nuwe Testament bereik word. Die koherensie tussen Ou en Nuwe Testament moet dus vanuit die Nuwe Testament gevind word. Alhoewel hy hierdie teologiseringspatroon nie in sy latere werk volg nie (vgl Oberholzer 1992b:73), het hierdie vroeëre denkpatroon aansienlike invloed uitgeoefen op die wetenskapbenadering van departementshoofde soos E S Mulder en J P Oberholzer, terwyl sy latere benadering meer invloed uitgeoefen het op A P B Breytenbach.

Daar tree aan die begin van die sewentigerjare aansienlike verandering in by die bestudering van Semitiese Tale. Dit het nie soseer met die ontdekking van nog meer Semitiese dialekte, soos Ugarities en Eblaities, of met die beskikbaarstelling van nog meer literatuur uit Qumran te doen nie, maar met die uitwerking van die moderne linguistiek wat met F de Saussure se Cours de linguistique generale van 1915 begin het. Deur die publikasies van James Barr (1968), Comparative philology and the text of the Old Testament, en Wolfgang Richter (1971), Exegese als Literatur Wissenschaft, is die benadering van die nuwer linguistiek ook op die terrein van die studie van Hebreeus en die Ou Testament oorgedra. In die plek van 'n historiesgeoriënteerde taalbenadering, kom 'n funksionele benadering wat op die gebruiksituasie van taal fokus. Taal word voortaan in sy organiese verband gesien as 'n sisteem van willekeurige tekens wat binne die lewende taalsituasie gestruktureer word om kommunikasie tussen gebruikers te bewerkstellig. Hierdie benadering was 'n belangrike stimulus vir die nuwe dinamiez-ekwivalente vertaling van die Bybel in Afrikaans, wat eventueel in 1983 verskyn het. Dit het ook 'n drastiese wending in die eksegese van die Ou Testament teweeggebring. Sedert die sewentigerjare het die klem telkens op een of ander aspek van die totale kommunikasiegebeure geval en is dit in die eksegese ondersoek met behulp van toepaslike metodes wat daarvoor ontwikkel is. Die eerste aspek wat besondere aandag ontvang het, was dié van die gestruktureerdheid van die taaluiting. Onder leiding van Ou Testamentici soos J A Loader en W S Prinsloo het 'n immanente leesmetode ontstaan wat die teks op die sinkroniese vlak ontleed het (vgl Le Roux 1993:28-33, 351-353). Hierdie teksimmanente benadering het neerslag gevind in verskillende doktorale tesisse wat sedertdien in die Departement OTW ingedien is, soos dié van A P B Breytenbach (1979), P M Venter (1981) en L C Bezuidenhout (1986). 
Die bestudering van Semitiese tale aan die Universiteit van Pretoria het ook baie sterk in die rigting van sinkroniese struktuurstudie beweeg. Sedert die begin van die sewentigerjare is in die betrokke departement baie klem gelê op die onderrigsituasie. Die bestudering van Semitiese tale is deur herkurrikulering meer praktykgerig gemaak. Dit beteken onder meer dat die missiestelling van die departement bestaan in 'die aankweek van 'n tekskompetensie' (Potgieter 1989:10) by sy studente. Omdat die unieke bydrae van die departement nog altyd 'in die literêre benadering tot tekste' (Potgieter 1989:10) gelê het, word besondere aandag aan die insigte van die taal- en literatuurwetenskap gegee. Volgens hierdie insigte bestaan 'n teks uit verskillende boustene wat op verskillende vlakke volgens bepaalde taalkonvensies met spesifieke kommunikatiewe funksies opereer. Die teksvaardigheid wat die student moet aanleer, is die vermoë om hierdie verskillende boustene waaruit die teks bestaan en die konvensies wat gebruik is, te kan identifiseer, analiseer en die kommunikatiewe funksie daarvan te kan vasstel. Nadat dit gedoen is, kan 'n teks eers gem̈terpreteer word. Tekskompetensie val hier saam met die vermoë om die teks struktureel-kommunikatief te kan analiseer.

Die beklemtoning van die sinkroniese aspek van taal is oor die laaste twee dekades in Suid-Afrika dikwels afgespeel teen die diakroniese studie daarvan. Die lang geskiedenis van histories-kritiese navorsing kon egter nie so maklik van die tafel gevee word nie. Navorsers wat in die histories-kritiese benadering geskool was, het hulle nie laat oortuig dat 'n sinkroniese benadering die enigste moontlike weg was nie. In die Departement OTW het $J$ P Oberholzer tot aan die einde van sy termyn in 1991 steeds voorkeur aan die diakroniese benadering gegee. Dit het by studente van die departement die nodige balans geskep. In die sogenaamde 'metodestryd' tussen die twee benaderings is dit veral F E Deist wat balans en groter diepgang gebring het. In sy werk het hy steeds gewys op die belang daarvan om die ekstratekstuele relasies van 'n teks saam met die intertekstuele relasies daarvan te ondersoek (vgl L.e Roux 1993:33-73). Deist kombineer die diakroniese en sinkroniese benaderings en beoefen 'grammaties-historiese eksegese' (Le Roux 1993:56). In sy benadering word alle aspekte van die teks wat bydra tot die betekenis daarvan, literêr sowel as histories, ondersoek. Deist se omvattende benadering is gebaseer op sy deurtastende ondersoek na die hermeneutiese onderbou van die eksegetiese metodes wat gebruik word. In aansluiting by die navorsing na paradigmavorming en epistemologie op die gebied van die teologie, wys Deist op die onderliggende filosofie en wêreldbeskouing van alle metodes wat in die eksegese van die Ou Testament gebruik word. Hy bepleit 'n skerp kritiese selfbewussyn by die eksegeet en die beoefening van 'n krities ingestelde hermeneutiek. 
Die insigte van Deist het groot invloed uitgeoefen op die hantering van die teks van die Ou Testament in die Departement OTW. Die vierdelige reeks, Die Literatuur van die Ou Testament, wat Deist en sy kollegas van die Departement Ou Testament aan Unisa in 1986 en 1987 uitgegee het, tel onder die werk wat in die departement voorgeskryf word. Die bestudering van die literatuur van die Ou Testament binne 'n breër kommunikatiewe konteks, is ook die benadering wat hier gevolg word. Die struktuur van die teks, maar ook die lewenskonteks waarin dit gefunksioneer het, sowel as die skrywers- en leserskonteks word in die ondersoek van die Ou-Testamentiese teks betrek. Die kreatiewe lees van die teks, waarvoor Deist hom in verskillende publikasies beywer het, word hier in die baan van die bepaalde teologiese benadering van die Hervormde Kerk se afdeling van die teologiese fakulteit gestuur.

Samevattend kan gesê word: Semitiese tale maak van OTW die bestudering van die Ou Testament as 'n teks wat vanuit 'n historiese konteks deur allerlei kommunikasie-strategieë met 'n leser só kommunikeer dat dit hom responderend in 'n leesproses betrek.

\section{DIE INVLOED VAN DIE DEFINISIE VAN TEOLOGIE IN DIE FAKULTEIT TEOLOGIE}

OTW staan nie net met die bestudering van Semitiese tale en ander geesteswetenskappe in 'n simbiotiese verhouding nie, maar ook met die ander teologiese dissiplines. Die basisteorie van OTW korreleer ook met die teologiese metateorie wat in die fakulteitsafdeling in omloop is. So was die histories-kritiese vakbenadering by OTW aan die begin van die eeu volkome versoenbaar met die algemene teologiebeskouing in die fakulteit. Dit was te wyte aan die invloed van die Etiese Teologie uit Nederland. Die Etiese rigting het sy teologiese wortels in die Switserse Reveil van die vroeg-negentiende eeu. Sy hoogbloei was in die kerkstryd van die laat-negentiende eeu in Nederland. Hierdie rigting kan getipeer word as '...overtuigd rechtzinnig en gebaseerd op de belijdenis, maar gekant tegen alle confessionalistisch theologiseren...' (Bakhuizen van den Brink \& Dankbaar 1968:181). Dit is 'n rigting met '...aandacht voor de verbinding van Christendom en cultuur....' (Bakhuizen van den Brink \& Dankbaar 1968:231). Danksy hierdie siening het 'n kombinasie van '...twee elemente, 'n breë kulturele visie op die opleiding en 'n gebondenheid aan die regsinnigheid...'n kenmerk gebly van die Hervormde teologiese oriëntering' (Loader 1989:414). Dit is veral te wyte aan die beskouing van die '...etiese karakter van die waarheid....' (Loader 1987:48) dat daar ruimte was vir die werk van Semitici in die teologiese arbeid van die Hervormde Kerk. Die siening '...dat die wese van 
die waarheid nie objektiveerbaar en rasionaliseerbaar is nie, maar dat die mens wel in aanraking daarmee kan kom' (Loader 1987:48) maak '...'n wetenskaplik-kritiese beoefening van die teologie moontlik...' (Loader 1987:55). Geloof en rede word hier in 'n enkele teorie tuisgebring sodat die rasionele, wetenskaplike komponent as die binnenste van twee konsentriese sirkels voorgestel word en die geloofskomponent as die buitenste (sien Loader 1987:54). Die siening 'dat geen leerstuk, dogma of sisteem die volle waarheid van God kan omvat nie en dat hulle net pogings is om die onsegbare te sê...' (Loader 1987:55) het die weg geopen vir die beoefening van die dialektiese Barthiaanse teologie in die teologiese fakulteit. 'In die lewenswerk van beide Gemser en Van Selms vind ons die tipiese kenmerke van hulle etiese vakgenote en voorgangers: ' $n$ Indringende kritiese sin, handhawing van sowel die historiese kritiek (teenoor die 'orthodoxie') as die kerklike belydenis (teenoor die vrysinnigheid), 'n aversie aan dogmatisme maar waardering vir kerklike verbondenheid' (Loader 1989:430).

Wanneer E S Mulder in 1956 hoof van die Departement OTW word, is die invloed van die dialektiese teologie alreeds in die fakulteit aanwesig. In toenemende mate het die probleem van die ekumeniese beweging en die konflik met A S Geyser ook ' $n$ rol begin speel. Mulder sluit in sy vakbeoefening aan by B Gemser, is soos Gemser ook by voorkeur geinteresseerd in eksegese, gaan histories-krities te werk, aanvaar etimologie en vergelykende taalkunde as legitieme verklaringswyses en toon besondere belangstelling in Bybelvertaling (vgl Breytenbach 1992:102-104). Binne die stroom van die Etiese denke aanvaar Mulder die noodsaaklike samehang van wetenskap en geloof, die noodwendige gebruik van histories-kritiese eksegese in die Reformatoriese Bybeluitleg en kies hy ook doelbewus '...vir die koppeling van 'n kritiese wetenskaplike benadering en 'n sterk verbondenheid met die kerk waarin daar gesoek word na die boodskap van die Ou Testament as oorkonde van die openbaring van God' (Breytenbach 1992:106-107).

Terwyl Mulder die noodsaak van 'n histories-kritiese benadering vir OTW in die teologiebeoefening aanvaar het, was dit egter vir hom 'n wesenlike probleem om sy vakgebied by sy teologisering uit te bring. Die koherensie van Ou en Nuwe Testament soek hy vanuit die Nuwe Testament met 'n hermeneutiese skema van belofte en vervulling. Die Ou Testament is vir hom in wese '...'n egte adventsboek.' (angehaal by Breytenbach 1992:110). In sy teologisering en prediking raak sy navorsingwerk verseil in 'n benadering dat daar 'n ontmoetingsgebeure met God plaasvind waarin die menslike aandeel geheel geminimaliseer word. Juis dit waaraan sy histories-kritiese navorsing gewy is, word daardeur irrelevant vir sy teologiese uitsprake. Hierdie verskynsel by Mulder lei tot die beoordeling van Breytenbach (1992:108): 'Hy het nie daarin geslaag om sy wetenskaplike arbeid en sy teologiebeoefening ten dienste van gelowiges in die kerk, ten volle te integreer nie'. 
Terwyl Breytenbach (1992:106) verskillende redes noem hoekom Mulder nie daarin geslaag het om die twee gebiede suksesvol te integreer nie, moet die saak bes moontlik sterker vanuit die tydsgewrig en die rol wat Mulder tydens en na die Geysersaak gespeel het, verstaan word. Hy het probeer om die moontlike wantroue by kerklike ampsdraers in wetenskaplike eksegese te temper en 'n potensiële trugolf teen 'n histories-kritiese benadering in die eksegese te help stuit (Breytenbach 1992:111). Daar was egter nog meer op die spel. Die opkomende ekumeniese beweging in die laat-vyftigerjare, die toenemende kritiek van Van Selms en Geyser teen Artikel III van die Kerkwet, die besluite van die Hervormde Kerk rondom Cottesloe, die Geysersaak in die vroeë sestigerjare, al hierdie sake het ' $n$ rol gespeel om agterdog by die kerkvolk teen akademici en hulle histories-kritiese vakbeoefening te wek. In die Herderlike Brief van die Algemene Kerkvergadering in Die Hervormer van Junie 1962 gaan dit oor '...belangrike uitgangspunte oor die teologiese opleiding en die vryheid van die eksegeet....' (Van Aarde 1992a:170). In die lig hiervan kan dit verstaanbaar wees dat Mulder as dekaan van die teologiese fakulteit en persoon met besondere belangstelling in die kerklike praktyk, dit gerade geag het om 'n teologiese profiel te handhaaf waarin die histories-kritiese navorsing 'n baie klein rol speel. Die algemene tendens in die Hervormde Kerk, teenoor die rigting wat Van Selms ingeslaan het (vgl Oberholzer 1992b:73), was in 'n meer dogmatiese rigting. Hierin het die benadering van lede van die fakulteit, soos die professor in Dogmatiek, 'n beinvloedende rol gespeel. Ten spyte van sy waardering vir Barth, het Barth vir B J Engelbrecht niks anders gesê as wat Calvyn reeds gesê het nie en het hy met die Calvyn-idioom volstaan (Koekemoer 1992:323). In hierdie keuse het die verwikkelinge op ekumeniese front en die probleme in die Hervormde Kerk in die vroeë jare sestig 'n besliste rol gespeel. Engelbrecht was bevrees dat ‘...die geskiedenis van die mens die ewigheid van God sou vervang en dat versoening en bevryding in die proses niks meer as ' $n$ intermenslike en politieke aangeleentheid sou word nie...' (Koekemoer 1992:323). Hierbenewens moet ook sy felle teenkanting teen enige teologiese denkrigting wat in die koers van modernisme en liberalisme op teologiese gebied beweeg, gesien word. Dit het geweldige sterk invloed op die teologie en kerklike denke van die Hervormde Kerk uitgeoefen. Sy keuse het weerklank gevind in die werk van sy kollega A D Pont wat ook van Barth af na Calvyn beweeg het (vgl Steenkamp 1992:277) en '...'n besondere eksponent van die "strenger" dogmatiese rigting' (Oberholzer 1992d:580) was.

Teenoor hierdie tendens om verankering in 'n konfessioneel-georiënteerde benadering te vind, het $F \mathbf{J}$ van $Z y l$ voorkeur gegee aan die denke van Barth. Sy voorganger, H P Wolmarans, het sy teologie op die openbaringsbegrip gebaseer. Saam 
met Brunner het hy Woordopenbaring bo natuuropenbaring as uitgangspunt gekies. Dit was ook sy oortuiging dat teologie ‘...wat gegrond is op 'n verkeerde openbaringsbegrip, moet die vrug en resultaat wees van 'n verkeerde gelcof en daarom moet die teologie wat die openbaring in Christus nie as die enigste openbaring aanvaar nie, 'n wetenskaplike bewerking van die ongeloof wees' (Van Zyl 1992:373). Ook Van Zyl neem die openbaringsbegrip as sy vertrekpunt. In aansluiting by Barth sien hy die Bybel as die menslike getuienis van die openbaring. In die hoor en lees daarvan word die Bybel die openbarende Woord van God. Ons het die Woord van God egter nie anders as in die menslike woord van die Bybelgetuienis nie. Hierdie menslike woord moet met behulp van die toepaslike wetenskappe, soos die histories-kritiese wetenskap, bestudeer word. Hierdie menslike woorde is die medium wat as sodanig nie openbaring is nie, maar wanneer dit ontleed en begryp is, word dit die instrument waardeur God Hom hier en nou openbaar. Soos by die Etiese rigting staan kritiese Skrifondersoek ook hier in diens van die teologie. Met hierdie Skrifbeskouing het Van Zyl nie net die dialektiese teologie in die teologiese fakulteit bevorder nie, maar die plek van OTW in die beoefening van die teologie aangedui. 'In 'n tyd toe 'n prekritiese Skrifgebruik algemeen gangbaar was in die Afrikaanse kerke en teologie (veertigerjare), stel Van Zyl dus 'n Skrifbeskouing wat die moderne Bybelwetenskap in 'n groot mate geantisipeer en verdiskonteer het' (Van der Merwe \& Van Wyk 1992:392).

Die vakbeoefening van J P Oberholzer, departementshoof van OTW vanaf 1971 , moet in die lig van aksente soos Wolmarans se beklemtoning van die openbaring in Christus as die enigste openbaring, die opkoms van histories-geïnteresseerde teologieë soos die 'heilshistoriese teologie' (Van der Merwe \& Van Wyk 1992:389; vgl Cullmann 1946 en herdrukke, Christus und die Zeit), die voortstuwing van die dialektiese teologie en die woelinge op politieke, ekumeniese en teologiese terrein in die sestigerjare, gesien word. Hy tree na vore in 'n tyd toe die klimaat ryp was vir teologiese vernuwing (Van Wyk 1992:26). By Oberholzer, anders as by Mulder, is daar 'n doelbewuste integrering van wetenskap en teologie. Hierin sluit hy by Van Selms aan, maar gaan op 'n meer sistematiese wyse te werk. Die sleutelbegrip in sy teologiese metateorie is 'die voortgaande selfopenbaring van God'. Dit is die kenobjek van die teologie. Die enigste sleutel tot hierdie objek is die Bybel. Op konsentriese wyse moet Bybelondersoek uitgebou word tot ensiklopediese teologiebeoefening wat in die kerklike praktyk uitmond. Vanuit die formele uitleg van die teks van die Ou Testament, waarin van al die ter saaklike dissiplines van die historiese kritiek gebruik gemaak word, beweeg die eksegese by Oberholzer deur na die volle konteks van die hele Skrif (vgl Venter 1992:114-117). Die samehang van 
die Skrif is daarin geleë dat dit getuienis is van die historiese gang van die reddende openbaring van God op Christus heen. Soos by die heilshistoriese benadering, moet die samehang van Ou en Nuwe Testament vanuit die Persoon van Christus verstaan word en elke gedeelte daarvan moet as getuienis op Christus heen hanteer word. Daar is nie een verabsoluteerde wyse waarop hierdie relasiestelling gedoen moet word nie. Dit kan op velerlei wyses gedoen word: 'n belofte-vervulling patroon, 'n Lutherse wet-evangelie patroon, ensovoorts. Hoewel Oberhelzer met verloop van tyd oor die metode van hierdie relasiestelling met al groter omsigtigheid gepraat het, het hy daarby bly staan dat dit 'n relasiestelling op Christus heen moet wees. Selfs wanneer hy saam met J A Sanders wegbeweeg van 'n historiese openbaringsmodel en meer begin praat van die Bybel as getuienis van die verhouding tussen God en mens wat beslag kry in die voortgaande vorming van die godsdiensgemeenskap, hou hy vol dat hierdie verhouding sy volste verwesenliking in Christus vind en van Hom uit verstaan moet word. Hierdie standpunt bied vir hom die ruimte om in sy vakbeoefening by die ander teologiese dissplines aan te sluit en ensiklopedies by kerklik relevante teologiebeoefening uit te kom.

Daar het sedert die sewentigerjare ook in die teologie 'n kennelike paradigmaverskuiwing gekom. Dit kan onder ander in Oberholzer se gebruik van die openbaringsbegrip aangetoon word. Waar sy teologiese metateorie aanvanklik met openbaring in heilshistoriese sin gewerk het, word dit later al meer openbaring in eksistensiële sin. In sy definisie van wetenskap as '...kritiese, sistematiese, kontroleerbare ondersoek, verklaring en beskrywing van die kenbare en die denkbare' (Oberholzer 1989:438), is '...wat God oor Homself bekend gemaak het en maak' (Oberholzer 1989:439; kursivering van die skrywer) die kenbare en die denkbare waarmee teologie as wetenskap werk. Hierdie voortgaande openbaring is die eksistensiële werklikheid waarmee teologie hom besig hou. Dit is die kenbare van teologie wat nooit klaar ondersoek en beskryf is nie. Wat van teologie 'n eiesoortige wetenskap maak, is dat hy hierdie voortrollende werklikheid eksklusief vanuit die Skrif ondersoek en beskryf - 'n geloofsoortuiging, 'n unieke grondparadigma dus, van waaruit teologie as wetenskap bedryf word. Die data in die Bybel, dit waarmee OTW hom besig hou, word as '...data van die selfbekendmaking van God' (Oberholzer 1989:439) ondersoek en beskryf. Hierdie beskrywing van Bybelse data '...in die vorm van kerklike simbole en liturgieë, die sistematiese ontwerp van kerklike leer en die spekulatiewe deduksie deur opeenvolgende geslagte van teoloë' (Oberholzer 1989:440), is in wese beskrywing van hoe die kerk en sy gelowiges homself sien. Die gevolgtrekking is: 'Teologie is daarom ook altyd antropologie' (Oberholzer 1989:440). Openbaring het in Oberholzer se metateorie eksisitensiële waarheid 
geword wat nie as 'n objek op 'n afstand bestudeer kan word nie, maar as 'n relasie met God waarin die teoloog self eksistensieel betrokke is. Hy bestudeer aan die hand van die Skrif 'n voortgaande openbaringsproses waarvan hy en sy tyd onlosmaaklik deel is.

Volgens H Ott werk teologie altyd met twee pole: 'die een is die openbaring wat in die Skrif opgeteken staan en die ander is die mens tot wie die openbaring gerig is' (Engelbrecht 1981:16). Teologie moet aandui in hoeverre hierdie twee pole bymekaar uitkom, 'in hoeverre die openbaring werklik openbaring is' (mededeling deur J H Koekemoer aan die Hermeneutiese Studiegroep op 24 Maart 1993). Teologie 'dui sinvolle samehange aan' en 'verskaf groter klaarheid oor dit wat in die geloofsbeslissing gedoen en gewaag word' (Engelbrecht 1981:16). Binne hierdie raamwerk moet OTW dus beoefen word om iets te kan bydra tot teologiese uitsprake oor sinvolle samehange en geloofsbeslissings wat in die eie tyd en omstandighede gemaak word. Daar is 'n eksistensiële geloofsdimensie aan OTW verbonde. Negatief gestel, beteken dit dat OTW sinneloos sou wees as dit die Bybel bestudeer 'as maar nog net een van die baie literêre produkte van mense. Ons lees die Skrif met die allernuutste literêre metodes, maar vind niks daarin oor die verhouding tussen God en mens nie...' (Boshoff 1981:16).

Die verskuiwing in teologiese metateorie vanaf historiese openbaring as objek van ondersoek, na 'n dinamies eksistensiële openbaringsbegrip, lei noodwendig tot nadere ondersoek van die kontekstuele situasie waarin openbaring plaasvind. Die dialektiese model van teologiebeoefening word gehandhaaf, maar ook verder uitgebou. Die teologie hou hom steeds besig met die verhouding tussen God en mens 'in terme van die Heilige Skrif as die klassieke en normatiewe model' (Van Aarde 1992b:960). Om werklikheidsbetrokke te wees vereis egter van die teologie om die kontemporére toneel te verdiskonteer. Daarom stel Van Aarde voor dat '...'n dialekties-teologiese model met die oog op die postmoderne mondiale kultuur' (1992b:972-973) soos volg daar sal uitsien:

Om kerk vandag te wees, bewustelik binne die reformatoriese tradisie en besonderlik die dialektiese teologie te bly en relevant te wees, vra 'n nuwe model van teologiebeoefening waarin die gansandersheid van God erken word, die eie-aard van die Christelike geloof, die postmoderne mondiale kultuur en die eis om nie net op die kognitiewe te bou nie, maar ook op die emotiewe en pragmatiese.

(Van Aarde 1992b:973) 
In hierdie voorstel word die konteks van die openbaring as 'n postmoderne mondiale kultuur verdiskonteer. Die kontemporêre tendens van die interaktiewe geheelvorming van pluriformiteite word hier in die teologiese metateorie ingetrek. Daar kan in so 'n nuwe denkmodel selfs sprake wees van 'n moontlike '...simbiotiese verhouding tussen metafoor, teologie en verbeelding ...deur die postmoderne projek gestig en gekonstitueer...' (Beukes \& Koekemoer 1993:604).

Klanke van hierdie nuwe benadering kan in A P B Breytenbach se intreerede by die aanvaarding van die hoofskap van die Departement OTW op 19 November 1992 gehoor word. Sy voordrag oor die dilemma van 'n teologie van die Ou Testament, verwoord die dilemma van 'n tyd wat nie langer met absolutismes kan werk nie. Die klem het verskuif na kontekstualiteit en begrippe soos pluriformiteit en interrelasionaliteit het aan die orde van die dag gekom. Breytenbach wys daarop dat die navorsingsresultate van die histories-kritiese ondersoek bevestig het '...dat die teologiese diversiteit van die Ou Testament van so 'n aard is dat 'n omvattende sistematisering van die inhoud wat 'n enkelvoudige beeld van die God van die Ou Testament in sy verhouding met mense oplewer, nie moontlik is nie' (Breytenbach 1993:5-6). Dit is vir hom ook nie wenslik dat hierdie diversiteit wegverklaar word nie, omdat alle uitsprake oor God in elk geval situasiegebonde is en altyd voorlopig is, omdat '...ons God en sy handeling onder ons nie in 'n sisteem kan vasvang nie' (Breytenbach 1993:8). Die pluriformiteit van teologiese uitsprake in die Ou Testament en die diversiteit van kontekste waarin uitsprake gemaak is, moet eenvoudig aanvaar word. Wat nodig is, is teologiese eksegese wat die Ou Testament in terme van God se verhouding met mense en die wêreld beskryf. Dit bly egter altyd voorlopige spreke omdat '...die waarheid van God nie gesê kan word nie, maar in die geloof beleef kan word' (Breytenbach 1993:9).

Breytenbach aanvaar die rol en plek van histories-kritiese navorsing in OTW. Hy maak ook 'n duidelike keuse vir beoefening van OTW binne die idioom van die dialektiese teologie. Dit gaan in OTW oor 'n verhouding met God wat in 'n ryke diversiteit van kontekste realiseer, wat eksistensieel beleef word maar waaroor altyd slegs tentatief geteologiseer kan word. Die duidelike afbakening van 'n teologiese grondparadigma en die verskuiwing weg van 'n historiese openbaringsmodel na 'n relasionele model waar teologiese uitsprake as menslike spreke vanuit die menslike begrensdheid en ervaring oor die Onbegrensbare God gesien word, is tipiese denke van die huidige tyd. Die kontekstualiteit van alle uitsprake, die pluriformiteit van sienswyses, die vraag na die interrelasie van alle gegewenhede, die relasionaliteit van die waarheid, die eksistensiële belewing eerder as enkelvoudige rasionalisering. is alles sake wat op die agenda vir bespreking staan van 'n tyd wat besig is om afskeid te neem van die moderniteit en stadigaan besig is om oor te beweeg na die 
era van post-moderniteit. OTW staan in hierdie tyd saam met die ander teologiese dissiplines voor die vraagstuk hoe teologie in die post-moderniteit beoefen moet word en hoe dit in hierdie veranderende tyd steeds deel kan bly van die universum van wetenskappe wat aan die universiteit beoefen word.

Samevattend kan gesê word: Die Bybels-reformatories-dialektiese metateorie wat in die teologiese fakulteit in omloop is, gee aan OTW ' $n$ basisteorie wat die resultate van sy ondersoek as grondparadigmas vir die ryk geskakeerde en pluriforme eksistensiële verhouding tussen God en mens sien.

\section{DIE INVLOED VAN DIE WETENSKAPSBEOEFENING AAN DIE UNIVERSITEIT}

\subsection{Wetenskapsteorie}

Die teologie is soos alle wetenskap organies verbind aan sy kontemporêre lewensruimte en lewenswerklikhede. Dit worstel met die problematiek van hierdie ruimte en probeer antwoorde vind wat relevant is vir sy tyd. Die tyd waarin teologie tans beoefen word, kan in breë trekke beskryf word as die wêreld van die postmoderne. Die hoofkenmerk van hierdie wêreld is die van '...pluralisme in de cultuur, in kunst en wetenschap' (Houdijk 1990:276). In hierdie wèreld laat 'n mens '...de vrije loop aan de oneindige pluraliteit van het leven' (Houdijk 1990:276). Die totalitêre en absolute denke van die verbygaande 'moderne' tydvak maak in hierdie wêreld al meer plek vir denke in terme van veelvuldigheid en diversiteit. Daar word al verder wegbeweeg van 'n reduksionisme waar stelsels slegs in terme van hulle onderdele gesien is. Die benadering is eerder holisties. Die sisteem word as een groot geïntegreerde geheel gesien, as 'n netwerk van geïntegreerde relasies. Dit bring noodwendig die vraag na vore hoe teologie in die kontemporêre postmoderne wêreld met sy radikale religieuse en kulturele pluralisme beoefen kan word. Hoe moet teologie met die kontemporêre denke met sy postmoderne verwysingsraamwerk kommunikeer? En as teologie in hierdie postmoderne wêreld nog steeds deel van die wetenskap wil wees, wat moet sy verhouding met die wetenskap wees?

Die vraagstuk word vanuit verskillende hoeke benader. Vir Seckler het teologie geen toekoms as hy nie in voortdurende dialaoog met die ander wetenskappe staan nie. 'Eine isolierte und in diesem Sinn "reine" Theologie gerat in kognitive Vereinsamung und wird wirklichkeitsleer, weltfern, kommunikationsarm und sektiererisch' (Seckler 1990:8). Omdat teologie ook wetenskap wil wees en soos alle wetenskap rasioneel en verklarend met die werklikheid wil omgaan, is daar tussen teologie en wetenskap 'n 'Verhaltnis elementarer positiver Zuordnung' (Seckler 1990:2). Die noodsaaklike dialoog tussen wetenskap en teologie moet op die drie 
terreine gevoer word van navorsingmetodiek, die grondparadigmas waaruit gewerk word en die gemeenskaplike verantwoordelikheid wat die wetenskap teenoor die gemeenskap het. Vanuit sy eiesoortige hoek moet die teologie in solidariteit met die wetenskap die gemeenskap dien. Teologie moet help koers gee aan die 'wirtschaflich-technischen Zivilisation' wat sonder '...Ruckbesinnung auf metaphysische, antropologische und eschatologische Orienterungdsdaten...' (Seckler 1990:8) eenvoudig nie op koers sal kan bly nie.

Shults (1992:227) praat van 'n 'symbiotic dialogue between theology and science' binne die konteks van 'n gemeenskaplike verandering in die epistemologiese struktuur van die verwysingsraamwerk van beide teologie en wetenskap. Hy sluit hierin aan by die werk van T F Torrance. Torrance het in die teologie van Barth en in die fisika van Einstein ' $n$ beweging na die 'natural inherence of form and being' (Shults 1992:226) gevind. Hulle beweeg weg van die logiese positivisme en kritiese rasionalisme met sy gefragmenteerde dualistiese denke en werk eerder met die ontologiese eenheid van die werklikheid. Barth hou hom nie besig met nadenke oor God op Homself of die mens op sy eie nie, maar met die God wat die mens ontmoet, en die mens in ontmoeting met God, en die dialoog en geskiedenis wat binne hierdie raamwerk plaasvind. Eweneens breek Einstein weg van Newton se teorie oor absolute tyd en ruimte met sy relatiwiteitsteorie. Die chaosteorie, wat Shults self op noëtiese vlak met teologie probeer korreleer, vind 'n paradoksale wetmatigheid in die onvoorspelbare manier waarop stelsels in die wêreld werk. Die onvoorspelbaarheid is egter daaraan te wyte dat soveel verskillende stelsels op soveel verskillende vlakke op mekaar inwerk. Wat chaoties in een stelsel mag lyk, blyk weer ordelik en sinvol blyk binne 'n groter stelsel. Vir Shults lè die taak van die teologie in die ondersoek en verklaring van die inwerking van die verlossingsteorie op die menslike stelsels: 'Theology inquires into the nature of God's redemption for human systems at all levels; families, churches and societies. This will continue to be the task of postmodern theological science' (Shults 1992:235).

Van Huyssteen sien die probleme van die teologie as 'n uitdaging wat aanvaar moet word. Enersyds word die kontinuiteit met die Christelike tradisie gehandhaaf en andersyds word volledig rekening gehou met die kontemporêre religieuse en kulturele pluralisme, sonder om in die slagyster te trap van enige vorm van politieke of konfessionele outoritêre absolutisme. Teologie tree in dialoog met die kontemporère kultuur en verken die raakvlakke met die res van die wetenskap. Die postmoderne tyd vereis dat die gefragmenteerde, gespesialiseerde wêreld van die natuurwetenskappe, in 'n sinvolle verhouding gestel moet word met die eweneens gefragmenteerde en gespesialiscerde werreld van die teologie. Ten spyte van die geweldige diversiteit, is daar tog wel 'n gemeenskaplike raakvlak tussen teologie en wetenskap. Hoewel Van Huyssteen spesifiek die dialoog tussen teologie en na- 
tuurwetenskap in die oog het, geld sy insigte ook op die gebied van die verhouding tussen teologie en die wetenskap in die algemeen. Dit gaan by albei om verstaanbaarheid (intelligibility), om die strewe daarna om op die diepste moontlike vlak te verstaan. Hierdie gemeenskaplikheid tesame met die aandrang op simbiose tussen die twee, is van wesenlike belang vir die beoefening van teologie: 'It also shapes our intellectual expression of the Christian faith and cautions us to greater epistemological and methodological sophistication' (Van Huyssteen 1993:119). Daar is nie meer ruimte in die hedendaagse teologiebeoefening vir 'epistemological innocence' (Van Huyssteen 1993:122) nie. Die verhouding tussen teologie en wetenskap lê primêr op die epistemologiese vlak. Dit is op die vlak van hulle kennisteorie waar bepaal moet word of die twee van mekaar verskil of verwant is. Om die raakvlakke tussen die twee te verhoog moet daar aanbeweeg word na 'n gemeenskaplike 'postmodern holist epistemology' (Van Huyssteen 1993:125). Teologie en wetenskap kan nie langer teen mekaar afgespeel word met 'n 'fondamentalistiese' (foundationalist) beroep op absolute kennis wat finaal en onomstootlik is en die prerogatief van die een bo die ander waarborg nie. Omdat menslike kennis 'n ontwikkelende sosiale fenomeen binne ' $n$ net van oortuigings is, kan nòg die teologie nòg die wetenskap hom beroep op enige vaster grond as die ander een. Die teologie kan nie op 'openbaring' teruggeval asof dit absolute kennis los van alle ander menslike kennis is nie. Teologie en wetenskap gebruik albei rasionele metodes om die begrip 'wetenskaplik' te verstaan. Albei probeer om binne 'n kognitiewe, evaluerende en pragmatiese konteks die mees koherente en beste rasionele verklaring vir sake te soek. Terwyl daar belangrike parallele bestaan tussen die verklarings wat teologie en wat wetenskap bied, figureer wetenskaplike verklarings meer op die interpersoonlike gebied en teologiese verklarings meer op die intiem persoonlike gebied. Teologiese navorsing gaan in op sake soos die vraag na die sin van die lewe en gee verklarings wat sin gee aan die lewe. Hoewel teologie met unieke vraagstukke en eiesoortige verklarings werk, en die rasionele denke in teologie soms met ander epistemiese waardes as wetenskap werk, is teologie niks minder rasioneel of kontekstueel as wetenskap nie. Teologie kan ook nie geloof as bewys vir sy uitsprake aangryp nie. Dit is 'n 'fideist misconstrual' (Van Huyssteen 1993:131). Die gelowige se poging om te verstaan vertoon presies dieselfde rasionele struktuur as dié van wetenskap. Teologiese verklarings is niks anders as rasionele konstruksies wat die relevansie van ' $n$ oorgelewerde tradisie in die konfrontasie met kontemporêre kontekstuele vraagstukke probeer verseker nie. Soos alle wetenskaplike uitsprake is teologiese verklarings ook maar feilbare en voorlopige hipoteses wat aan korreksie en hersiening onderworpe is. Teologiese verklarings moet daarom oop staan vir kritiek en indringende ondersoek. Van Huyssteen verwoord dit soos volg: 
And since all attempts to clarify Christian beliefs necessarily involve dependence on categories not drawn from the Christian tradition, as well as the use of general notions such as truth, meaning, coherence and reference, Christian theology will always find itself in necessary discourse with other theologies and with the science and philosophy of its time.

(Van Huyssteen 1993:131)

Teologie het van sy kant af ook 'n bepaalde rol om te speel. Die homogene informasie-tegnologiese kultuur wat hom mondiaal oor alle kulture uitbrei, vang die mens vas in 'n immateriële wêreld van beelde en tekens. Hy dreig om kontak met die wêreld van die sintuiglike, materiële dinge te verloor. In die postmoderne wereld lei dit tot 'n poging om die balans te herstel. Daar is ' $n$ '...neue Suche nach "Religion", nunmehr allerdings im wesentlichen verstanden als Heilsmittel fur die Sinn- und Orientierungskrisen der von der Komplexität der Verhältnisse überforderten Individuen' (Kaufmann 1991 :269. Dit is 'n beweging na 're-sacralisation' (Glebe-Möller 1992:30). Mense begin nou weer 'religious language games' (GlebeMöller 1992:30) te speel. Hulle skep meestervertellings waarin die wêreld gesien word as 'n relasie van ' $n$ oorweldigende pluraliteit van sake, waaronder ook die niefisiese. Teologie is self ook deel van hierdie taalspel. Dit is 'God-Talk' (GlebeMöller 1992:33), wat oor God en sy plek binne hierdie relasie van pluriformiteite praat. Om te kan saampraat en 'n betekenisvolle rol in hierdie taalspel te speel, om 'n beïnvloedende meestervertelling te kan aanbied, sal teologie in nie-teologiese terme vertaal moet word: 'That is the only possibility of theology in a postmodern world' (Glebe-Möller 1992:33). Dit moet so funksioneer in die huidige wêreld dat dit mense se lewensloop kan verander. Daarom moet teologie op ortopraksis, eerder as ortodoksie konsentreer (vgl Glebe-Möller 1992:39). Hy moet in terme van die hedendaagse praktyk homself uitspreek. Daarom is dit nodig dat 'een theologie en een ethiek ontwikkeld worden die de mense "vermaterialiseren": een fundamenteel "materialistische" theologie' (Houdijk 1990:294). Dit moet hierin gaan om 'een levende lichamelijkheid van de mens' (Houdijk 1990:294). Dit beteken nie dat die teologie verval in 'n oppervakkige deugde-etiek nie, maar dat die mens in sy totale liggaamlikheid, sy totaliteit van hande, voete en oë, betrek word. Die mens in sy totaliteit staan in interaksie met die pluraliteit waarin hy leef. Hier word doelbewus weggebreek van 'n hegemoniese verabsolutering van een sisteem. Miskotte het gewaarsku daarteen om God se openbaring in 'n geslote sisteem te probeer vasvang. Die dialektiese teologie het hierin die pad getoon en die bevrydingsteologie met sy 
differensiedenke voorgespring, deur in die omvattende verhouding met God ruimte te laat vir die 'anderse' en die 'vreemde'. Dit gaan om die verhouding met die lewende God, waar die mens in sy ryk verskeidenheid, ook in sy materiële, met God in verhouding staan.

Die koers wat die teologie moet inslaan, is dié van 'de waarheid in relatie' (Informatiedienst 1981:6). Danksy die bepaalde perspektiewe wat in die Ou Testament voorkom, kan OTW met gemak binne so 'n teologiese raamwerk beweeg. Weiser het reeds in die dertigerjare die oorhoofse siening in die OT as 'dynamische Wirklichkeitverständnis' (Weiser 1961:185) getipeer. Die waarheid word in die Ou Testament altyd uitgebeeld as 'n gebeure. Dit is geen abstrakte gegewe wat los van tyd en plek kan bestaan nie. Dit is altyd iets wat binne die totale samehang van mens en wêreld ervaar word.

Das Verstehen und Erkennen der Wahrheit im Alten Testament, die Erfassung der Wahrheit als Wirklichkeit ist also das Sichhineinstellen in ein Geschehen, oder das dynamische Erffasstwerden von einem Geschehen, bei dem es sich weniger um das Dasein und Sosein von Dingen handelt, als vielmehr um die ganze Existenz, um das Sein oder Nichtsein des erkennenden Menschen selbst.

(Weiser 1961:187)

So, byvoorbeeld, is die perspektief in Spreuke 1-9 dié van 'n realiseerbare totaliteitsmodel. Die doelwit wat daar gestel word is die 'integrering van mens en wêreld in een harmonieuse geheel' (Venter 1991:1097). In Levitikus 19 word toewyding aan God as lewensomvattende opdrag gesien. 'Vir die Israeliet bestaan daar nie 'n segmentering van sy lewe nie. Alle aspekte van sy bestaan is integraal verweef, soos wat sy bestaan as mens solidêr verweef is met die bestaan van sy volk en met die voortbestaan van die ganse skepping' (Venter 1993:5).

Die unieke van die Ou Testament is natuurlik daarin geleë dat hierdie dinamiese verstaan van die werklikheid altyd van God uit en in relasie tot Hom gesien word. Dit is die grondwaarheid waaruit die OTW werk. Dit bepaal ook die aard en opdrag van OTW: 'Als theologische Aufgabe hat sie es mit der Besinnung auf die Wirklichkeit des Menschen zu tun, insofern diese durch die Wirklichkeit Gottes bestimmt ist' (Weiser 1961:191). Vanuit hierdie besinning bied OTW relevante verklarings aan die mens van die hede: 'Unsere Aufgabe ist es jedoch, in der Konkretheit unserer geschichtlichen Situation, die gerade uns und nur uns gegeben ist, jene letzte Beziehung des Menschen zur Gotteswirklichkeit zu erkennen, die dort und hier, damals und heute die gleichen sind' (Weiser 1961:195-6). 
Samevattend: Die grondliggende siening in die Ou Testament van 'n geïntegreerde leefwereld waarin die mens in sy totaliteit in 'n allesomvattende lewensverhouding met God staan, stel OTW daartoe in staat om aanklank by die huidige wetenskapsheskouing te vind. OTW kan as teologiese dissipline op sinvolle wyse in dialoog tree met die ander wetenskappe, omlat hy 'n epistemologiese raakvlak met hulle het.

\subsection{Wetenskap aan die universiteit}

OTW word as wetenskap aan die universiteit bedryf. Die aard en wese daarvan word bepaal deur die rol wat teologie aan die universiteit vervul. . Vanaf die ontstaan van die universiteitswese in Europa in die middeleeue was teologie deel van hierdie 'huis van die wetenskappe'. Dit is steeds beoefen as wetenskap onder die wetenskappe wat soos die ander ondergeskik is aan '...den Gesetzmässigkeiten der institutionellen Wissenschaftsorganisation und den Ritualen der Akademischen Forschung und Lehre' (Seckler 1990:3). Teologie het egter met verloop van tyd sy posisie as koningin van die wetenskappe verloor. Meer nog, dit het onder bedreiging gekom en die gevaar begin loop om selfs sy plek aan die universiteit te verloor. Hierdie proses het alreeds in die vorige eeu begin, toe die belang van die natuurwetenskappe oorheersend geword het. Die maatstaf vir wetenskaplikheid was die epistemologiese benadering wat in die natuurwetenskappe geheers het. Dit het per definisie aan die geesteswetenskappe en aan die teologie al minder ruimte aan die universiteit gelaat. Uit die bepaalde wetenskapsteoretiese oogpunt het dit 'n vraag geword of teologie nog kan geld as wetenskap wat aan die universiteit tuishoort.

Deur die twee wêreldoorloë van die twintigste eeu en die ekologiekrisis van die jongste tyd het daar egter 'n 'Sinnerosion' (Baumgartner 1991:283) van die wetenskappe ontstaan. Die verwoesting wat die mens se kennis in die wêreld en die natuur aangerig het, het ' $n$ ander benadering tot wetenskap teweeggebring. Wetenskap het kennis binne 'n groter, omvattender konteks geword. Dit is in diens van die breë gemeenskap gestel. Die praktyk het bepalend vir die navorsing en opleiding aan die universiteit geword. Die Duitse universiteit het 'n 'Ausbildungsdienstleistungsgrossbetrieb' (Lubbe, in Baumgartner 1991:297) geword, wat vanuit 'n 'Nützlichkeitsgesichtspunkte' (Kaufman 1991:270) volgens 'dem Berufsleben zugewandten Effektivităt' (Wirsching 1991:302) gemeet word. Hierdie tendens het ook in die Suid-Afrikaanse universiteitswese sy verskyning gemaak, hier gekombineer met die bepaalde sosio-ekonomiese omstandighede van die land. Ook hier word die wetenskappe met 'funksionalistiese en materialistiese kriteria (Potgieter 1989:7) gemeet. Vakke word afgeskaf indien dit nie "konkrete aantoonbare korttermyn nuttigheidswaarde' (Potgieter 1989:7) het nie. 'Die wetenskap word reeds tot die absurde toe gekwantifiseer en tot getalle verding sodat enige besinning oor teologie aan 'n universiteit met hierdie "aanslag" sal moet rekening hou' (Le Roux 1992:291). 
Naas hierdie kwantifisering van wetenskap het daar 'n bepaalde beskouing oor godsdiens posgevat wat die teologie in 'n moeilike posisie plaas. Godsdiens word toenemd as 'n private aangeleentheid gesien. Dit is 'n opsie wat 'n persoon uitoefen naas ander persoonlike keuses wat hy moet maak. Binne die diversiteit en pluriformiteit van die gemeenskap is die Christelike geloof een godsdiens naas baie ander. Die probleem van die plek en rangorde van die Christendom in die huidige wêreld is tegelyk die probleem van die plek van teologie aan die universiteit. Uit die hoek van die politieke wetenskap word gevra hoekom die sekulêre staat finansiering van onderrig en navorsing in teologie moet verskaf as dit dan 'n opsie is wat slegs deur ' $n$ bepaalde persentasie van sy burgers in persoonlike belang uitgeoefen word. Dit is steeds die 'Bekenntnis- und Kirchengebundenheit' (Seckler 1991:244), die geloofsbinding van die teologie en sy kerklike afhanklikheid (Baumgartner 1991:278), wat telkens as spits van die argument gebruik word om beswaar te maak teen die teenwoordigheid van teologie aan die universiteit. Indien teologie dan tog aan die universiteit moet voortbestaan, word daarop aangedring dat dit 'als wissenschaftliche Wahrnehmung des Religiösen (im weitesten Sinne)' (Wirsching 1991:314) bedryf moet word en nie deur die geïnstitusionaliseerde godsdiens of die belydeniskerk bepaal mag word nie. Teologie moet deur 'n godsdienswetenskaplike fakulteit vervang word.

Verskillende argumente kan aangevoer word hoekom teologie aan die universiteit moet bly. Die universiteit is tog die '...hochste Institution im Bildungssystem einer Sozietät...' (Baumgartner 1991:298). Die universiteit moet teologie huisves, nie primêr op grond daarvan of dit as wetenskap kwalifiseer volgens een of ander maatstaf al dan nie, of ter wille van die besondere sosiale funksie van die teologie deur die kerk in die gemeeenskap nie, maar omdat die universiteit, '...einen Institution des Studiums verschiedenartigster Disziplinen....' (Baumgartner 1991:283) is. Die universiteit sal 'oneindig armer' (Le Roux 1992:292) wees en selfs sy identiteit prysgee as teologie weggelaat sou word. Binne die raamwerk van die universiteitswetenskappe is teologie '...ein Anwalt des tiefen menschlichen Verlangens nach Sinnorientierung' (Hünermann 1991:329). In die gemeenskap van 'geleerdes en lerendes wat hulle op die studie van die een werklikheid vestig...dra die teologie by tot die mens se kennis aangaande die een groot werklikheid' (Le Roux 1992:292). Die kerk het die opdrag om die Christelike boodskap te verkondig en ook in die openbaar te verdedig. Teologie moet hierdie taak in die akademiese gemeenskap verrig. Daar is ook geen ander wetenskap aan die universiteit wat met soveel ander wetenskappe 'n verbintenis het as die teologie nie. 
Teologie is egter nie net vir die universiteit van wesensbelang nie, maar ook die universiteit is vir die voortbestaan van teologie van uiterste belang. Sou teologie by die universiteit weggaan, sal dit sy status as wetenskap in die samelewing verloor en sal dit tot blote esoteriese kennis op dieselfde vlak as natuurgenesing of astrologie vervaag. Teologie bly ook ten diepste afhanklik van die ander wetenskappe, soos die linguistiek, sosiologie en geskiedskrywing, om werklik teologie te kan wees. Dit is net aan die universiteit waar wedersydse wetenskaplike beïnvloeding kan plaasvind.

In die lig van hierdie argumente het die teologiese fakulteite daarom 'n dubbele opdrag: 'Sie haben einerseits Professionalisienungsaufgaben, indem sie Personal für den kirchlichen Dienst...vorbereiten. Sie haben andererseits Legitimationsaufgaben, indem sie die Sache des christlichen Glaubens vor dem Forum menschlicher Vernunft rechtfertigen' (Kaufmann 1991:272). Die plek waar hierdie dubbele funksie van teologie die beste uitgevoer kan word, is die universi-teit: 'Die institutionelle in der Universität verfasste Theologie...scheint am ehesten geeignet, dieses spannungsreiche Verháltnis in sich auszutragen' (Kaufmann 1991:277). Teologie sal sowel 'n funksionele as ' $n$ idealistiese benadering moet volg (vgl Le Roux 1992:294295). Dit sal op universiteitsvlak daarop afgestem moet wees 'om die bes moontlike opgeleide en gevormde kandidaat vir die bediening daar te stel' (Van der Merwe 1992:411), maar tegelyk ook die teologie in 'n godsdienstige-pluralistiese gemeenskap te bevorder deur volgehoue navorsing en intensiewe teologisering. By sy studente moet daar geskep word ' $n$ '...intellektuele houding...sodat die student probleme in sy beroeplewe kan hanteer (Le Roux 1992:296). Om hierdie doel binne die opset van die universiteit te bereik, verg noukeurige kurrikulering. Die kurrikulum sal daarop ingestel moet wees om al die teologiese dissiplines as een span saam te snoer. Hierdie integrasie van teologiese vakke kan op verskillende vlakke onderneem word, vanaf die vak-saaklike vlak tot die mees sentrale 'metateologiese, normatief-paradigmatiese vlak' (mededeling deur P J vd Merwe aan die Hermeneutiese Studiegroep op 24 Maart 1993). Hierdie kurrikulering sal so ingerig moet wees dat dit ook binne die raamwerk van die missiestelling van die universiteit val. Die missiestelling van die Universiteit van Pretoria is daarop gerig dat hy hom ‘...onmisbaar [wil] maak deur welvaartskepping en verhoging van die lewensgehalte van die inwoners van die land, deur hom slegs te rig op dit wat uitnemend verrig kan word' (Raamwerk [1993]:5). In sy gemeenskapsgerigtheid wil die universiteit aan die markbehoeftes voldoen, wat onder andere insluit '...dat daar ook aan die geestelike en kulturele behoeftes van gemeenskappe voldoen moet word....' (Raamwerk [1993]:6). Vanuit sy bepaalde beskouing van 'geestelike en kulturele 
behoeftes' sal die teologie aan die universiteit dan ook lewensrelevant en lewensverrykend moet opereer. Van OTW vereis dit enersyds groter samewerking met die ander teologiese dissiplines en inder wetenskappe en andersyds groter gerigtheid op die teologiese relevansie van sy vakinhoud (vgl Oberholzer 1992a:64).

Samevattend: OTW is binne die raamwerk van die universiteit dcarop gerig om in interaksie met die ander teologiese dissiplines en ander wetenskappe aan die universiteit, teoloë te vorm wat lewensrelevante teologie in die gemcenskap kan bedryf.

\section{Literatuurverwysings}

Bakhuizen, J N \& Dankbaar, W F 1968. Handboek der kerkgeschiedenis: De kerk zeden de zeventiende eeuw, vierde deel. Den Haag: Bakker.

Baumgartner, H M 1991. Von der Königin der Wissenschafte zu ihren Narren? Theologische Quartalschrift 171, 278-299.

Beukes, C J \& Koekemoer, J H 1993. Metafoor, teologie, verbeelding: 'n Postmoderne beskouing. HTS 49, 595-608.

Boshoff, P B 1981. Ons moet terug na die bron. Die Hervormer 3 Junie 1981, bl 16. Breytenbach, A P B 1992. Egge Simon Mulder, hoogleraar 1956-1970. HTS 48, 101-112.

Breytenbach, A P B 1993. Die dilemma van 'n teologie van die Ou Testament.

Intreerede gelewer op 19 November 1992. Universiteit van Pretoria. (Nuwe Reeks nr 286.)

Engelbrecht, B J 1981. Is teologie 'n wetenskap?, Die Hervormer 3 Junie 1981, bl 16. Glebe-Möller, J 1992. The possibility of theology in a postmodern world. Studia Theologica 46, 29-39.

Houdijk, R 1990. De mens onttroond? Het postmoderne denken en de theologie. Tijdschrift voor Theologie 30, 276-297.

Hünermann, P 1991. Die Theologie und die universitas litterarum. Theologische Quartalschrift 171, 316-329.

Informatiedienst 1981. God met ons: Over de aard van het Schriftgezag. Utrecht: Tijl-Libertas.

Kaufmann, F-X 1991. Theologie zwischen Kirche und Universität. Theologische Quanalschrift 171, 265-277.

Koekemoer, J H 1992. Dogmatiek en Christelike Etiek binne die Fakulteit Teologie (Afd A) aan die Universiteit van Pretoria. HTS 48, 315-328.

Le Roux, J H 1992. Op die breuklyn (oor universiteit en teologiese fakulteit). NGTT 33, 291-300.

- 1993. A stony of two ways: Thirty years of Old Testament scholarship in South Africa. Pretoria: Verba Vitac. (Old Testament Essays [New Series] Supplement No 2.) 
Loader, J A 1987. 'Tertium datur' - oor die etiese waarheidsbegrip. HTS 43, 47-57.

- 1989. Ontstaan en eerste periode van die Hervormde teologiese opleiding aan die Universiteit van Pretoria. HTS 45, 412-437.

Oberholzer, J P 1989. Teologie as wetenskap: Aantekeninge van buite die sistematiese teologie. HTS 45, 438-441.

- 1992a. Die Ou-Testamentiese Wetenskap in die Fakulteit Teolgie (Afd A), Universiteit van Pretoria, 1917-1982. HTS 48, 59-65.

- 1992b. Adrianus van Selms, deeltydse dosent 1938-1962. HTS 48, 67-82.

Oberholzer, J P 1992c. Berend Gemser, hoogleraar 1926-1955. HTS 48, 83-100.

- 1992d. Terugblikke op die Fakulteit Teologie (Afd A), Universiteit van Pretoria, en sy lede - 'n literatuurverkenning. HTS 48, 575-584.

Potgieter, J H 1989. Semitiese tale - verlede, hede en toekoms aan die Universiteit van Pretoria. Intreerede gelewer op 1 Junie 1989, Universiteit van Pretoria. (Nuwe Reeks nr 254.)

Raamwerk vir Strategiese Beplanning 1993-1997 [1993]. Universiteit van Pretoria.

Seckler, M 1990. Der christliche Glaube und die Wissenschaft. Theologische Quartalschrift 170, 1-9.

Shults, F LeRon 1992. A theology of chaos: An experiment in postmodern theological science. SJTh 45, 223-236.

Steenkamp, J J 1992. Die teologiese gerigtheid van die Departement Kerkgeskiedenis 1957-1992. HTS 48, 273-291.

Van Aarde, A G 1992a. A S Geyser, teologiese dosent 1946-1961. HTS 48, 159-182.

- 1992b. Hoe praat ons oor/van God? Teologiese idiome van gister en van vandag. HTS 48, 957-976.

Van der Merwe, P J \& Van Wyk, D J C 1992. Francois Jacobus van Zyl, hoogleraar 1960-1978. HTS 48, 381-405.

Van Huyssteen, J W 1993. Theology and science: The quest for a new apologetics. The Princeton Seminary Bulletin, 14/1 New Series, 55-63. 